\title{
Analisis Sektor Pertanian Terhadap Pertumbuhan Pembangunan Ekonomi Di Provinsi Jambi
}

\author{
oleh: \\ *) Nurdin, S.E., M.E. \\ *) Muhammad Sabyan, S.E., M.E. \\ **) Dosen Tetap STIE Muhammadiyah Jambi
}

\begin{abstract}
Abstrak
Pertanian merupakan salah satu sektor Basis yang mempunyai peranan yang sangat penting dalam kelangsungan perekonomian di Indonesia. Dengan baik nya perjalanan sektor pertanian maka otomatis akan mempengaruhi laju pertumbuhan perekonomian negara kita. Dengan mempertimbangkan hal tersebut di atas maka dengan ini penulis merasa tertarik untuk lebih jauh meneliti sektor tersebut dalam skala yang ada di Provinsi Jambi.
\end{abstract}

Katakunci : Pertanian, Perekonomian Indonesia

\section{PENDAHULUAN}

\section{Latar Belakang Penelitian}

Pembangunan pada hakikatnya itu merupakan rangkaian kegiatan dengan memanfaatkan seluruh potensi sebagai modal dasar yang efektif dan efisien melalui perencanaan dalam rangka meningkatkan kesejahteraan masyarakat dengan usaha merealisasikan pelaksanaan pembangunan yang lebih baik dan cepat. Pembangunan ialah suatu proses multidimensional yang mencakup proses perubahan struktur sosial, sikap masyarakat dan lembaga nasional yang berakselerasi tingkat kemiskinan (Todaro, 2009).

Pada dasarnya pembangunan ekonomi untuk meningkatkan kesejahteraan rakyat, begitu pula dengan pembangunan ekonomi di Indonesia, yang mana sebagai salah satu Negara berkembang. Indonesia selalu berusaha untuk meningkatkan taraf hidup rakyatnya dengan cara mengadakan pembangunan di segala bidang yang sesuai dengan tujuan pembangunan dan keinginan rakyat demi tercapainya masyarakat adil dan makmur yang merata baik materil maupun spiritual. Arah kebijakan ekonomi adalah pengembangan perekonomian yang berorientasi pada kemajuan teknologi dan membangun keunggulan kompetitif berdasarkan keunggulan komperatif sebagai Negara agraris. Selain itu pembangunan ekonomi harus berbasis dan sesuai dengan kompetisi produk unggulan disetiap daerah, terutama setelah adanya otonomi daerah pelaksanaan pembangunan daerah tentu saja tidak terlepas dari ketersediaan dana untuk pembiayaannya. Pembiayaan bagi pelaksanaan pembangunan daerah 
dituangkan dalam anggaran pembangunan. Selama ini anggaran pembangunan daerah terbagi atas anggaran pembangunan yang termasuk APBD dan anggaran pembangunan yang di kelola oleh instansi vertikal didaerah. Melalui kewewenangan yang diberikan oleh UU 32/2004 kepada daerah dalam penyelenggaraan otonomi daerah maka berbagai kelemahan dalam penyusunan dan pengelolaan anggaran pembangunan daerah diharapkan dapat disempurnakan. Dengan kewenangan yang dimiliki darah dapat menyusun perencanaan pembangunan yang sesuai dengan kebutuhan daerah dan aspirasi masyarakat. Anggaran pembangunan yang disusun dengan memperhatikan keseimbangan antara kebutuhan dengan kemampuan daerah tentu akan lebih efektif dibandingkan dengan anggaran pembangunan yang disusun dengan prinsip keseragaman antar daerah. Anggaran pembangunan tersebut diharapkan dapat mengatasi terjadinya pemborosan sebagai akibat program pembangunan yang tumpang tindih.

Jika pembangunan yang dimaksudkan untuk kesejahteraan kehidupan rakyat, maka dalam konteks Negara Indonesia pembangunan harus ditekankan di wilayah pendesaan, lebih khusus lagi rakyat yang bergulat pada kegiatan pertanian. Ada beberapa alasan untuk menjelaskan hal tersebut, pertama, pertanaian merupakan sektor yang bertanggung jawab menyediakan kebutuhan pangan masyarakat sehingga eksistensinya mutlak diperlukan. Kedua, sektor pertanian merupakan sektor yang bertanggung jawab menyediakan bahan baku bagi sektor industri dapat terus berlangsung. Ketiga, sektor pertanian memberikan kontribusi meningkatkan besarnya devisa Negara dengan komoditas yang dapat di ekspor. Keempat, pertanian merupakan sektor yang menyediakan kesempatan kerja bagi tenaga kerja di pedesaan, $75 \%$ dari seluruh angkatan kerja Indonesia bekerja di sektor pertanian.

Sektor pertanian sebagai salah satu sektor penyumbang terbesar dalam Produk Domestik regional Bruto (PDRB) masih diharapkan akan dapat mendorong perkembangan kegiatan perekonomian Indonesia. Hal tersebut tergambar dari sumbangan atau kontribusi sektor pertanian pada pembangunan ekonomi yang cukup besar terutama dalam hal penyediaan surplus pangan pada penduduk yang semakin menigkat, penyediaan akan bahan baku industri, tambahan penghasilan devisa dari ekspor produk pertanian, peningkatan pendapatan daerah dalam memperbaiki kesejahteraan rakyat khususnya pedesaan (Jhingan, 2000)

Demikian pula propinsi jambi yang salah satu Propinsi di Indonesia dengan cirri-ciri sebagai daerah pertanian. Hal hal ini dapat dilihat dari kondisi alam yang cocok untuk di kembangkan adalah Budidaya pertanian. Potensi pertanian di provinsi jambi tersebut sangat 
besar, hal ini hal ini dapat dilihat dari perannya yang penting dari sektor tenaga kerja di propinsi jambi pendesaan banyak bekerja dan bermata pencarian di bidang pertanian ini memberikan gambaran bahwa sector pertanian memegang peranan penting dalam kegiatan perekonomian di provinsi jambi.

Salah satu indiktor penting yang dapat digunakan untuk mengukur keberhasilan pembangunan ekonomi suatu daerah adalah Produk Domestik Regional Bruto (PDRB). PDRB mencerminkan keberhasilan setiap sector ekonomi dalam aktifitas produksi. Dalam konteks PDRB sektor pertanian, keberhasilan peningkatan produksi hasil pertanian jelas akan memberikan pengaruh terhadap peningkatan PDRB secara total.

Selama periode 2003-2013 PDRB Provinsi Jambi menunjukan kecendrungan yang meningkat sebagaimana tergambar pada table berikut ini :

Tabel 1.1 Perkembangan PDRB Propinsi Jambi Periode 2003-2013Berdasarkan Harga Konstant Tahun 2000 (dalam Rp.juta)

\begin{tabular}{|c|c|c|c|c|c|c|c|c|c|c|c|}
\hline $\begin{array}{c}\text { Lapangan } \\
\text { Usaha }\end{array}$ & 2003 & 2004 & 2005 & 2006 & 2007 & 2008 & 2009 & 2010 & 2011 & 2012 & 2013 \\
\hline Pertanian & 3.079 .258 & 3.193 .568 & 3.334 .406 & 3.467 .458 & 3.643 .690 & 3.811 .540 & 1.472 .612 & 4.437 .448 & 4.691 .195 & 5.003 .441 & 5.259 .856 \\
\hline Pertambangan & 1.192 .253 & 1.542 .686 & $\begin{array}{l}1.606 .186 \\
\end{array}$ & $\begin{array}{l}1.561 .951 \\
\end{array}$ & $\begin{array}{ll}1.702 .121 \\
\end{array}$ & $\begin{array}{l}1.588 .492 \\
\end{array}$ & $\begin{array}{l}1.847 .753 \\
\end{array}$ & $\begin{array}{l}1.614,206 \\
\end{array}$ & $\begin{array}{l}.851 .478 \\
\end{array}$ & $\begin{array}{l}1.875 .312 \\
\end{array}$ & 2.146 .442 \\
\hline Industri & 1.408 .195 & 1.459 .246 & 1.511 .509 & 1.644 .399 & 1.605 .804 & 1.769220 & 1.732 .833 & 1.948 .460 & 2.058 .460 & 2.137 .252 & 2.233 .275 \\
\hline Listrik & 548.031. & 581.160 & 674.457 & 823.483 & 930.801 & 978.240 & 105.047 & 109.744 & 117.731 & 128.646 & 145.524 \\
\hline Bangunan & 204.586 & 207.983 & 278.653 & 353.314 & 444.302 & 535.289 & 570.983 & .654 .223 & 721.482 & 782.474 & 853.368 \\
\hline Perdagangan & 1.609 .354 & 1.654 .981 & 1.748 .812 & 1.859 .317 & 1.971 .469 & 2.149 .765 & 2.319 .674 & 6.542 .612 & 2.562 .858 & 2.764 .830 & 3.045 .833 \\
\hline Pengangkutan & 7.49 .595 & 810.308 & 853.743 & 895.951 & 953.896 & 1.021 .598 & 1.082 .250 & 1.159 .479 & 1.198 .512 & 1.268 .174 & $1.318 / 770$ \\
\hline Keuangan & 364.404. & 331.850 & 342.253 & 390.117 & 446.225 & 483.787 & 511.717 & 609.271 & 754.770 & 889.519 & 997.305 \\
\hline Jasa-jasa & 906.789 & 946.851 & 1.038 .412 & 1.088 .419 & 1.126 .294 & 1.162 .453 & 1.209 .748 & 1.277 .751 & 1.341 .488 & 1.142 .145 & 1.482 .880 \\
\hline PDRB & 9.569 .242 & 10.205 .592 & 10.803 .423 & 11.343 .279 & 11.953 .885 & 12.612 .972 & 13.363 .620 & 14.275 .161 & 15.297 .770 & 15.274 .907 & 17.465 .253 \\
\hline
\end{tabular}

Sumber : BPS Provinsi Jambi 2011

Berdasarkan tabel diatas tergambar bahwa sektor pertanian memberikan sumbangan besar dalam struktur PDRB Provinsi Jambi. Hal ini memberikan gambaran bahwa sector pertanian berperan menjadi penggerak utama dalam kegiatan pertumbuhan pembangunan daerah.

Besarnya angka sumbangan PDRB sektor pertanian terhadap PDRB total Provinsi Jambi diatas mencerminkan bahwa sektor ini dalam perekonomian Provinsi Jambi sangat dominan dan sangat penting perannya dibandingkan sektor lainnya dalam struktur perekonomian Provinsi Jambi. Mengigat peran yang sangat strategis dan tipologi daerah Jambi yang sangat cocok dikembangkan sebagai daerah lahan pertanian maka diperlukan kajian yang mendalam mengenai factor-faktor yang dapat mendorong atau memperngaruhi perkembangan PDRB Sektor Pertaniandi Provinsi Jambi. 


\section{Perumusan Masalah}

Berdasarkan latar belakang di atas maka rumusan masalah penelitian sebagai berikut Berapa besar kontribusi sektor pertanian terhadap pertumbuhan ekonomi di Provinsi Jambi dan

Apakah sektor pertanian merupakan Komoditas Basis di Propinsi Jambi ?

\section{Tujuan Penelitian}

Adapun tujuan penelitian ini adalah: Untuk Menganalisis seberapa besar kontribusi sektor pertanian terhadap pertumbuhan ekonomi daerah Provinsi Jambi danUntuk mengetahui apakah sektor pertanian merupakan komoditas yang basis di Provinsi Jambi.

\section{Manfaat Penelitian}

Penelitian ini dapat dijadikan sebagai bahan masukan guna membuat kebajikankebajikan dalam rangka implementasi menuju tindakan praktisi untuk meningkatkan komoditas sektor pertanian

\section{TINJAUAN PUSTAKA}

\section{Konsep Pembangunan Ekonomi}

Menurut Sadono( 2000 ) Ilmu ekonomi adalah suatu bidang ilmu pengetahuan yang sangat luas liputannya atau suatu study mengenai individu-individu dan masyarakat membuat pilihan dengan atau tanpa dengan uang. Pembangunan Ekonomi berarti suatu proses yang menyebabkan pendapatan perkapita penduduk suatu masyarakat meningkat dalam jangka panjang, sedangkan Pertumbuhan Ekonomi adalah perkembangan kegiatan dalam perekonomian yang menyebabkan barang dan jasa yang di Produksikan dalam masyarakat bertambah dan kemakmuran masyarakat meningkat.

Menurut Hadi Prayitno (2000) Pembangunan Ekonomi adalah Kemajuan dalam kondisi hidup dan untuk itu pertumbuhan ekonomi dan Industrialisasi tampaknya merupakan jalan keluar yang tidak dapat di tolak

Menurut Irawan dan Suparmoko( 2003 ) Pembangunan Ekonomi adalah untuk meningkatkan taraf hidup suatu bangsa yang sering kali di ukur dengan tinggi rendahnya pendapatan riil perkapita dengan tujuan pembangunan ekonomi untuk menaikkan pendapatan nasional riil juga untuk meningkatkan produktivitas 
Pembangunan Ekonomi yang dapat memberikan kepada manusia kemampuan yang lebih besar untuk menguasai alam sekitarnya dan mempertinggi tingkat kebebasannya dalam mengadakan suatu tindakan tertentu. Oleh karena itu pembangunan ekonomi perlu dilaksanakan demi kehidupan yang layak.

Pembangunan haruslah sebuah perencanaan dan proses yang ditujukan untuk merubah keadaan menjadi lebih baik dan haruslah terpadu dan multidimensional artinya pembangunan harus mencakup segala bidang untuk mewujudkan peningkatan sedangkan pertumbuhan pembangunan ekonomi adalah suatu proses kehidupan masyarakat dari suatu tahap pembangunan ekonomi ke tahap pembangunan ekonomi lainnya. Sering dikacaukan antara pertumbuhan ekonomi dengan pembangunan ekonomi. Sementara pembangunan ekonomi bukan saja untuk meningkatkan pertumbuhan ekonomi, tetapi mencakup menyelessaikan persoalan-persoalan ekonomi lainnya seperti menurunkan ketimpangan pendapatan baik antara individu, kelompok dan wilayah. Dalam hal pembangunan daerah termasuk mengurangi ketimpangan investasi dan tenaga kerja, kemudian juga memperluas kesempatan kerja atau menurunkan tingkat pengangguran. Seharusnya semakin tinggi pembangunan ekonomi akan semakin kecil ketimpangan investasi dan tenaga kerja atau sebaliknya ketimpangan akan kecil bila menurunnya ketimpangan investasi dan tenaga kerja.

Pelaksanaan pembangunan daerah tentu saja tidak terlepas dari ketersediaan dana untuk pembiayaannya. Pembiayaan bagi pelaksanaan pembangunan daerah dituangkan dalam anggaran pembangunan. Selama ini anggaran pembangunan daerah terbagi atas anggaran pembangunan yang termasuk dalam APBD dan anggaran pembangunan yang di keloa oleh instansi vertikal di daerah. Anggaran pembangunan daerah pada umumnya bersumber dari bantuan pembangunan yang di berikan oleh pemerintah pusat (Sukirno,2005). Bantuan pembanguna yang diberikan oleh pusat kepada daerah terdiri atas bantuan umum dan bantuan khusus. Bantuan umum pada prinsipnya ialah bantuan dana yang diserahkan penggunaannya kepada daerah dalam rangka pembangunan daerah, sedangkan bantuan khusus penggunaannya ditetapkan oleh pemerintah melalui Inpres.

Melalui kewewenangan yang diberikan oleh UU 32/2004 kepada daaerah dalam menyelenggarakan otonomi daerah maka berbagai kelemahan dalam penyusunan danpengelolaan anggaran pembangunan daerah diharapkan dapat disempurnakan. Dengan kewenangan yang dimiliki daerah maka dapat menyusun perencanaan pembangunan yang sesuai dengan kebutuhan daerah dan aspirasi masyarakat. Perencanaan pembangunan tersebut dapat disesuaikan dengan dengan kebutuhan dan kemampuan daerah. Anggaran 
pembangunan yang disusun dengan memperhatikan keseimbangan antara kemampuan dengan kebutuhan daerah tentu akan lebih efektif dibandingkan dengan anggaran pembangunan yang disusun dengan prinsip keseragaman antar daerah Anggaran pembangunan tersebut diharapkan dapat mengatasi terjadinya pemborosan sebagai akibat program pembangunan yang tumpang tindih.

Secara ideal, kira pengelola keuangan daerah yang bersumber dari PAD, Dana perimbangan, pinjaman daerah dan lain-lain pendapatan yang sah merupakan kewenangan daerah maka penggunaan untuk anggaran pembangunan akan lebih efektif. Pengalokasian dana tersebut ke dalam anggaran pembangunan tentu harus berdasarkan pengkajian dan pertimbangan yang matang. Mustahil daerah akan mengalokasikan sejumlah dana tanpa melalui perencanaan yang matang, karean hal ini dapat menjadi pemborosan baik keuangan daerah. Dalam tahap awal pelaksanaan otonomi daerah banyak daerah mengalami shock akibat terbatas nya Dana Alokasi Umum (DAU) yang dapat dialokasikan untuk anggaran pembangunan karna sebagian besar dana tersebut terserap untuk anggaran belanja rutin. Namun dengan demikian kita harus yakin bahwa hal ini akan dapat disempurnakan secara bertahap namun sehingga pada saatnya nati sejalan dengan peningkatan kapasitas SDM, Keuangan dan Kelembagaan daerah akan mampu menyusun dan mengelola anggaran pembangunan sebagaimana diharapkan.

\section{Konsep Pertumbuhan Ekonomi}

Pertumbuhan ekonomi merupakan suatu gambaran mengenai dampak pembangunan yang dilaksankan khususnya dalam bidang ekonomi. Pertumbuhan tersebut merupakan laju pertumbuhan yang dibentuk dari berbagai macam sektor yang terjadi bagi suatu daerah. Indicator ini penting untuk mengetahui keberhasilan pembangunan yang telah dicapai dan berguna untuk menentukan arah kebijaksanaan pembangunan dimasa yang akan datang.

Para Ahli ekonomi telah mengartikan "Pertumbuhan Ekonomi dalam berbagai pengertian, diantaranya menurut Boediono (2000), pertumbuhan ekonomi adalah suatu proses kenaikan output dalam jangka panjang, dan Sukirno (2000) mengartikan pertumbuhan ekonomi sebagai perkembangan kegiatan dalam perekonomian yang menyebabkan barang dan jasa yang diproduksi dalam masyarakat serta kemakmuran masyarakat meningkat.

Untuk melihat tingkat ekonomi yang dicapai pada suatu tahun tertentu digunakan indikator pendapatan nasional. Maka untuk mengetahui tingkat pertumbuhan ekonomi harus 
membandingkan pendapatan nasional dari tahun ke tahun. Adapun faktor-faktor yang mempengaruhi pertumbuhan ekonomi suatu Negara adalah (Surno,2010)

1. Tanah dan kekayaan alam

Kekayaan suatu Negara meliputi luas dan kesuburan tanah, keadaan iklim dan cuaca, jumlah dan jenis hasil hutan dan hasil laut yang dapat diperoleh serta jenis-jenis barangtambang. Kekayaan alam dapat mempermudah untuk membangun perekonomian suatu Negara, terutama pada masa permulaan dari proses pertumbuhan ekonomi.

2. Jumlah dan mutu penduduk serta tenaga kerja

Penduduk bertambah dari waktu ke waktu dapat menjadi pendorong atau penghambat pertumbuhan ekonomi. Penduduk yang bertambah akan memperbesar jumlah tenaga kerja dan memungkinkan Negara itu menambah produksi dan memperluas pasar serta meningkatkan ekonomi.akibat buruk dari pertambahan penduduk terhadap pertumbuhan ekonomi terutama dihadapin oleh masyarakat yang kemajuan ekonominya belum tinggi tetapi telah menghadap kelebihan penduduk, dimana jumlah penduduk tidak seimbang dengan faktor-faktor produksi lainnya, ini berarti penambahan penggunaan tenaga kerja tidak akan menimbulkan pertumbuhan dalam tingkat produksi atau pun kalau ditambah pertumbuhan tersebut lambat sekali dan tidak mengimbangi pertambahan penduduk akibatnya pandapatan perkapita akan menurun yang pada akhirnya akan menimbulkan kemerosotan atas kemakmuran masyarakat.

3. Luas pasar sebagai sumber pertumbuhan ekonomi

Di Negara maju perekonomiannya luas pasar sangat penting peranannya dalam menentukan cepatnya pertumbuhan ekonomi (Sukirni, 2003).

Pertumbuhan ekonomi merupakan salah satu Indikator dalam mengukur hasil yang dicapai dalam waktu ke waktu di dalam suatu wilayah. Pertumbuhan ekonomi tersebut dapat dilihat dari perkembangan Produk Domestik Regional Bruto (PDRB) wilayah tersebut.

\section{Sektor Pertanian}

Dalam pengertian sempit pertanian di definisikan sebagai pertanian rakyat yaitu usaha pertanian keluarga di mana produksi bahan makanan seperti beras, palawija dan tanaman holtikultura seperti sayur dan buah-buahan. Sedangkan pertanian dalam pengertian luas mencakup pertanian rakyat dalam artian sempit, perkebunan, (perkebunan rakyat dan perkebunan besar oleh pihak swasta ), kehutanan, peternakan, dan perikanan baik perikan darat maupun perikanan laut. 
Sektor pertanian sebagai sektor pemimpin (leading sektor) harus mampu memacu dan mengangkat pembangunan sektor-sektor lainnya, seperti sektor industri, sektor pertambangan, sektor komunikasi, pengangkutan dan sektor lainnya.

Peran sektor pertanian dalam struktur perekonomian di Indonesia pada saat ini telah ditelaah dalam pembentukan PDRB, selain juga sebagai penyumbang dalam pembentukan PDRB, sektor pertanian juga berperan dalam penyerapan tenaga kerja, dan perluasan kesempatan kerja, serta dapat meningkatkan penerimaan Devisa melalui dari peningkatan ekspor dari komoditi pertanian.

Pada awalnya pertanian di definisikan sebagai budaya tanaman dan ternak, yang kemudian di manipulasi sedemikian rupa dengan pengetahuan dan teknologi yang ada.

Peran sektor pertanian dalam struktur perekonomian di provinsi jambi bila dilihat dari pembentukan PDRB, selain dalam penyumbang terbesar dalam pembentukan PDRB dalam provinsi jambi, sektor pertanian juga berperan dalam hal penyerapan tenaga kerja dan perluasan tenaga kerja serta dapat meningkatkan penerimaan dana kas daerah melalui peningkatan ekspor dari komoditi-komoditi dari sektor pertanian.

\section{Otonomi Daerah}

Lahirnya kebijakan otonomi daerah berdasarkan Undang-Undang Nomor 32 Tahun 2004 tentang pemerintahan daerah merupakan jawaban atas tuntutan Reformasi Politik dan Demokratisasi serta pemberdayaan masyarakat daerah. Setelah selama hampir seperempat abad kebijaksanaan otonmi daerah di Indonesia mengacu kepada Undang-Undang Nomor 5 tahun 1974 tentang pokok-pokok pemerintahan di daerah, pelaksanaan otonomi daerah tersebut membawa beberapa dampak bagi penyelenggaraan Pemerintah Daerah.

Diantaranya yang paling menonjol selama ini adalah Dominasi pusat terhadap daerah yang menimbulkan besarnya ketergantungan daerah terhadap program-program pembangunan daerahnya. Demikian dengan sumber keuangan penyelenggaraan pemerintahan yang diatur oleh pusat.

Prinsip-prinsip pemberian Otonomi Daerah dalam UU 32/2004 adalah:

1. Penyelenggaraan Otonomi daerah dilaksanakan dengan memperhatikan Aspek Demokrasi, Keadilan, Pemerataan serta potensi dan keanekaragaman daerah.

2. Pelaksanaan Otonomi Daerah didasarkan pada otonomi luas, nyata dan bertanggung jawab. 
3. Pelaksanaan Otonomi Daerah yang luas dan utuh diletakan pada Daerah Kabupaten dan Daerah Kota.

4. Pelaksanaan Otonomi Daerah harus sesuai dengan Konstitusi Negara sehingga tetap terjamin hubungannya yang serasi antara pusat dan Daerah serta antara daerah.

5. Pelaksanaan Otonomi Daerah harus lebih meningkatkan kemandirian daerah otonom, karenanya dalam Daerah Kabupaten dan Daerah Kota tidak ada lagi wilayah yang Administrarif.

6. Pelaksanaan Otonomi daerah harus sesuai lebih meningkatkan peranan fungsi Badan Legislatif Daerah, baik sebagai fungsi legislative, fungsi pengawas maupun fungsi anggaran atas penyelenggaraan pemerintahan daerah.

7. Pelaksanaan azas Dekonsentrasi diletakkan pada daerah propinsi dalam kedudukannya sebagai wilayah administrates untuk melaksanakan pemerintah tertentu yang di limpahkan kepada Gubernur sebagai Wakil Pemerintah.

8. Pelaksanaan azas tugas pembantuan di mungkinkan, tidak hanya dari pemerintah kepada derah desa yang disertai dengan pembiayaan sarana dan prasarana, serta sumber daya manusia dengan kewajiban melaporkan pelaksanaan dan mempertanggung jawabkan kepada yang menegasakannya.

\section{METODE PENELITIAN}

Metode penelitian merupakan system yang mutlak dalam suatu penelitian. Penelitian skripsil ini termasuk penelitian yang menganalisa data sekunder. Yang dimaksud dengan analisa data sekunder adalah analisa data-data yang telah dilaporkan oleh suatu bada, sedangkan badan ini tidak langsung mengumpulkan sendiri, melainkan diperoleh dari pihak lain yang telah mengumpulkan terlebih dahulu dan menerbitkannya (Singarimbun, 2008)

\section{Jenis Data}

Dalam penilitian ini data yang akan diolah dan dianalisis untuk kepentingan penelitian adalah data adalah data sekunder. Data sekunder ialah data yang berkala yang di kumpulkan untuk menggambarkan tentang perkembangan suatu kegiatan dari waktu ke waktu (time series) selama kurun waktu 2003-2013yang mana meliputi data PDRB sektor pertanian dan sub sektornya serta data PDRB secara keseluruhan Provinsi Jambi, yang meliputi : Data 
PDRB total Provinsi Jambi baik berdasarkan harga konstan 2000 dan berdasarkan harga nasional (Indonesia) periode 2003-2013

Untuk menjawab tujuan penelitian pertama untuk menghitung kontribusi PDRB Provinsi Jambi digunakan formulasi sebagai berikut ; (Dillon, 1999)

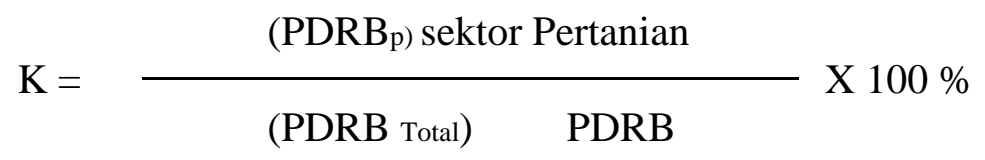

Dimana :

$\mathrm{K}=$ Kontribusi PDRB sektor pertanian terhadap PDRB Propinsi Jambi $(\%)$

$\mathrm{PDRB}_{\mathrm{p}} \quad=\mathrm{PDRB}$ sektor pertanian Provinsi Jambi berdasarkan harga konstan

PDRBTotal = PDRB Provinsi Jambi secara keseluruhan Berdasarkan harga konstan

Sementara untuk menjawab tujuan penelitian ke dua yaitu untuk mengetahui apakah komoditas sektor pertanian tersebut merupakan komoditas basis atau tidak basis digunakan formulasi sebagai berikut :

$\mathrm{Yi} / \mathrm{Yt}_{\mathrm{t}}$

$\mathrm{Yi} / \mathrm{Yt}_{\mathrm{t}}$

$\mathrm{LQ}=$

Dimana :

$\mathrm{Yi}_{\mathrm{i}}=\mathrm{PDRB}$ Sektor Pertanian Provinsi di Provinsi Jambi

$\mathrm{Yt}=$ PDRB Total Provinsi Jambi

$\mathrm{Yi}=$ PDRB Sektor Pertanian Nasional (Indonesia)

$\mathrm{Yt}=$ PDRB Total Nasional (Indonesia)

Dengan ketentuan :

Jika di sebut sector basis nilai LQ $>1$, dan non basis apabila $\mathrm{LQ}<1$.

\section{PEMBAHASAN HASIL PENELITIAN}

Sektor pertanian mempunyai prospek untuk pertumbuhan pembangunan ekonomi provinsi jambi. Hal ini disebabkan karena wilayah jambi sangat cocok dikembangkan berbagai komoditas pertanian. Potensi ini apabila dikembangkan lebih lanjut akan menjadi dukungan bagi perkembangan perekonomian provinsi di jambi. Untuk lebih jelasnya perkembangan PDRB sektor pertanian di Provisi jambi dapat dilihat pada table berikut : 


\section{Tabel 1}

Perkembangan PDRB Provinsi Jambi Periode 2003-2013 berdasarkan Harga Konstan 2000 (dalam Rp.juta)

\begin{tabular}{|c|c|c|}
\hline Tahun & $\begin{array}{c}\text { PDRB Sektor Pertanian } \\
\text { (Rp. Juta) }\end{array}$ & $\begin{array}{c}\text { Perkembangan } \\
\text { (persen) }\end{array}$ \\
\hline 2003 & 9.569 .242 & - \\
\hline 2004 & 10.205 .592 & 6.64 \\
\hline 2005 & 10.803 .423 & 5.85 \\
\hline 2006 & 11.343 .279 & 4.99 \\
\hline 2007 & 11.953 .885 & 5.38 \\
\hline 2008 & 12.619 .972 & 5.57 \\
\hline 2009 & 13.363 .620 & 5.89 \\
\hline 2010 & 14.275 .161 & 6.82 \\
\hline 2011 & 15.297 .770 & 7.16 \\
\hline 2012 & 16.274 .907 & 6.38 \\
\hline 2013 & 17.465 .253 & 7.31 \\
\hline & Rata - rata & 6.19 \\
\hline
\end{tabular}

Sumber : BPS Provinsi Jambi (data di olah)

Selama kurun waktu 2003-2013 Perkembangan PDRB Provinsi Jambi menunjukan kecenderungan yang meningkat, meskipun sempat mengalami penurunan pada tahun 2006, yaitu sebesar 4.99 persen, ini adalah salah satu dampak dari adanya krisis ekonomi yang dimana semua sektor pembentukan PDRB lainnya kecuali sektor pertanian mengalami resesi, dimana nilai kurs Rupiah melemah, dan tingkat inflasi yang tinggi, meskipun sebelumnya sempat mengalami peningkatan pada tahun 2003 - 2004, yaitu sebesar 6.64\%. pertumbuhan PDRB Provinsi Jambi berdasarkan harga konstan 2000 terjadi pada tahun 2011, yaitu sebesar 7.16\%. tingginya laju pertumbuhan PDRB yang tinggi pada tahun ini disebabkan stabilitas politik dan keamanan di tambah dengan iklim investasi yang kondusif bagi pembangunan nasional khususnya di Provinsi Jambi, akibatnya aktifitas dunia usaha berjalan lancar dan setiap proyek pembangunan dapat diselesaikan dengan tepat waktu ditahun selanjutnya yaitu 2013 mengalami peningkatan lagi sebesar $7.31 \%$ dan nilai rata - rata total PDRB Provinsi Jambi berdasarkan atas harga konstan 2000 yaitu sebesar $6.19 \%$

\section{Perkembangan PDRB Sektor Pertanian Provinsi Jambi}

sektor pertanian turut memberikan andil terhadap pembentukan PDRB Provinsi Jambi. Keberadaan sector pertanian mempunyai prospek untuk dikembangkan lebih lanjut dalam 
perekonomian Provinsi Jambi. Hal ini disebabkan karena wilayah jambi sangat cocok dikembangkan berbagai komoditas perkebunan. Potensi ini apabila dikembangkan lebih lanjut akan menjadi pendukung bagi perkembangan perekonomian Propinsi Jambi. Hal ini disebabkan karena wilayah ambi sangat cocok dikembangkan berbagai komoditas perkebunan. Potensi ini apabila dikembangkan lebih lanjut akan menjadi pendukung bagi perkembangan perekonomian Provinsi Jambi.

Untuk lebih jelasnya perkembangan PDRB sektor pertanian di Propinsi Jambi dapat dilihat pada tabel berikut ini :

Tabel 2

Perkembangan nilai PDRB Sektor pertanian Provinsi Jambi Tahun 2003-2013 berdasarkan Harga Konstan 2000 (dalam \%)

\begin{tabular}{|c|c|c|}
\hline Tahun & Dalam jutaan & Atas Dasar Harga Konstan 2000 \\
\hline 2003 & 3.079 .258 & 3.71 \\
\hline 2004 & 3.293 .569 & 4.84 \\
\hline 2005 & 3.348 .406 & 3.55 \\
\hline 2006 & 3.467 .458 & 5.08 \\
\hline 2007 & 3.643 .690 & 4.60 \\
\hline 2008 & 3.811 .540 & 11.34 \\
\hline 2009 & 4.243 .612 & 4.56 \\
\hline 2010 & 4.437 .448 & 5.71 \\
\hline 2011 & 4.691 .195 & 6.65 \\
\hline 2012 & 5.003 .834 & 5.12 \\
\hline 2013 & 5.259 .856 & 55.16 \\
\hline & Rata - rata & \\
\hline
\end{tabular}

Sumber : BPS Provinsi Jambi (data diolah).

Berdasarkan tabel tersebut tercermin selama periode 2003 - 2013 perkembangan PDRB sektor pertanian terhadap PDRB Provinsi Jambi menunjukan kecenderungan yang meningkat. Laju pertumbuhan menunjukan cenderung meningkat. Laju pertumbuhan sektor pertanian tertinggi di Provinsi Jambi terjadi pada tahun 2009 yaitu sebesar 11.34\%. tingginya laju PDRB sektor pertanian pada tahun 2009 tidak terlepas dari meningkatnya produksi sektor pertanian, terutama di sub sektor perkebunan yang ditopang oleh perkebunan besar seperti 
karet, sawit dan kelapa. Laju pertumbuhan terendah pada tahun 2006, yaitu sebesar $3.55 \%$. rendahnya laju pertumbuhan sektor pertanian pada tahun tersebut, akibatnya nilai produksi sektor pertanian tidak optimal selama periode 2003 - 2013 laju pertumbuhan PDRB sektor pertanian di Provinsi Jambi adalah sebesar 55.16\% pertahun.

\section{Kontribusi Sektor Pertanian terhadap PDRB Provinsi Jambi}

Peningkatan PDRB sektor pertanian secara absolute semestinya diikuti dengan kontribusinya terhadap PDRB Provinsi Jambi, potensi ini apabila dikembangkan lebih lanjut akan menjadi dukungan bagi perkembangan perekonomian Provinsi Jambi. Untuk lebih jelasnya perkembangan PDRB sektor pertanian di Provinsi Jambi dapat dilihat pada tabel berikut :

\section{Tabel 3}

\section{Kontribusi PDRB Sektor Pertanian terhadap PDRB Provinsi Jambi tahun 2003 - 2013} atas dasar harga konstan 2000 ( dalam \%)

\begin{tabular}{|c|c|c|c|}
\hline Tahun & $\begin{array}{c}\text { PDRB Total } \\
\text { ( Rp Juta })\end{array}$ & $\begin{array}{c}\text { PDRB Sektor } \\
\text { Pertanian } \\
\text { (RP. Juta })\end{array}$ & $\begin{array}{c}\text { Kontribusi } \\
\text { ( Persentase })\end{array}$ \\
\hline 2003 & 9.569 .242 & 3.079 .258 & 3,10 \\
\hline 2004 & 10.205 .592 & 3.293 .569 & 3.09 \\
\hline 2005 & 10.803 .423 & 3.348 .406 & 3.22 \\
\hline 2006 & 11.343 .279 & 3.467 .458 & 3.27 \\
\hline 2007 & 11.953 .885 & 3.643 .690 & 3.28 \\
\hline 2008 & 12.619 .972 & 3.811 .540 & 3.31 \\
\hline 2009 & 13.363 .620 & 4.243 .612 & 3.14 \\
\hline 2010 & 14.275 .161 & 4.437 .448 & 3.21 \\
\hline 2011 & 15.297 .770 & 4.691 .195 & 3.26 \\
\hline 2012 & 16.274 .907 & 5.003 .834 & 3.25 \\
\hline 2013 & 17.465 .253 & 5.259 .856 & 3.32 \\
\hline \multicolumn{3}{|c}{ Rata - rata } & 3.22 \\
\hline
\end{tabular}

Sumber : BPS Provinsi Jambi ( data diolah ).

Berdasarkan tabel 3 tercermin bahwa periode 2003 - 2013 kontribusi PDRB sektor pertanian terhadap PDRB Provinsi Jambi menunjukan kecenderungan yang menurun, kontribusi PDRB sektor pertanian tertinggi terjadi pada tahun 2003, yaitu sebesar $3.10 \%$. tingginya kontribusi PDRB sektor pertanian pada tahun ini tidak terlepas dari nilai absolute PDRB sektor pertanian yang terbesar, disamping peranan sektor lainnya belum mengalami perkembangan yang sangat signifikan. Kontribusi PDRB sektor pertanian terhadap PDRB 
Provinsi Jambi terendah terjadi pada tahun 2004, yaitu sebesar 3.09\%. rendahnya Kontribusi pada tahun 2004 disebabkan pada tahun ini kebijakan pemerintah di bidang politik kurang maksimal sehingga berdampak pada sektor pertanian, akan tetapi dampak tersebut tidak lama sehingga tahap demi tahap pun kontribusi pertanian meningkat sampai tahun 2008, dan di tahun 2009 kontribusi PDRB sektor pertanian terhadap PDRB Provinsi Jambi kembali mengalami penurunan sebesar 3.14\% dikarenakan sebagian wilayah Provinsi Jambi sedang mengalami gagal panen dan berimbas kepada penurunan produksi hasil pertanian berpengaruh positif dan signifikan terhadap PDRB sektor pertanian di Provinsi Jambi. Selama periode 2003 - 2013 kontribusi PDRB sektor pertanian terhadap PDRB Provinsi Jambi secara rata rata adalah sebesar $3.22 \%$.

\section{Sektor Basis (Location Quetion) antara sektor pertanian Provinsi Jambi terhadap PDRB Sektor Pertanian Indonesia}

Sektor basis merupakan sektor ekonomi yang mempunyai peranan sangat penting dalam perekonomian suatu wilayah atau sektor basis dapat dikatakan sebagai sektor andalan dalam perekonomian wilayah

Untuk melihat basis atau tidaknya suatu sektor pertanian dalam pertumbuhan ekonomi bagi pembangunan daerah secara periode 2003 - 2013, wilayah Provinsi Jambi maka perlu dilakukan perhitungan. Pendekatan perhitungan tersebut adalah dengan metode Location Quotion ( LQ ) yang dilakukan dengan menggunakan suatu indikator pendapatan yaitu PDRB Provinsi Jambi periode 2003 - 2013

Dengan ketentuan apabila hasil perhitungan lebih besar dari 1 ( LQ>1) maka sektor tersebut pada periode 2003 - 2013 dapat dikatakan sebagai sektor basis di wilayah dan tahun tersebut, sedangkan jika yang diperoleh dari perhitungan tersebut lebih kecil dari 1 ( LQ <1 ) maka sektor tersebut dikatakan sebagai sektor non basis bagi perekonomian wilayah pada periode tersebut. Dan apabila hasil dari perhitungan yang terjadi adalah 1 ( $L Q=1$ ) maka wilayah tersebut dikatakan tidak melakukan ekspor dan juga tidak melakukan impor komoditas tersebut. Dengan kata lain komoditas tersebut hanya mampu memenuhi kebutuhan dalam wilayah tersebut dan tidak dapat memenuhi permintaan wilayah lain pada analisis ini pertama menggunakan indikator pendapatan ( PDRB tahun 2003 - 2013 ) tingkat Provinsi Jambi yaitu sektor pertanian PDRB Provinsi Jambi terhadap PDRB Nasional sektor Pertanian Nasional di peroleh angka koefisien lokasi yang menggambarkan suatu sektor menjadi basis atau non basis sebagai berikut : 


\section{Tabel 4}

Nilai Location Qoution ( LQ ) komoditas sektor pertanian dengan indikator pendapatan atas dasar harga konstan Provinsi Jambi terhadap sektor pertanian dengan indikator Pendapatan Nasional Indonesia

\begin{tabular}{|c|c|c|c|c|c|}
\hline \multirow[t]{2}{*}{ Tahun } & \multicolumn{2}{|c|}{ Prov Jambi } & \multicolumn{2}{|c|}{ Nasional / Indonesia } & \multirow{2}{*}{$\begin{array}{c}\text { Location } \\
\text { Quetion } \\
\text { ( LQ ) }\end{array}$} \\
\hline & $\begin{array}{l}\text { PDRB S. } \\
\text { Pertanian }\end{array}$ & $\begin{array}{c}\text { PDRB } \\
\text { Total }\end{array}$ & $\begin{array}{c}\text { PDB S. } \\
\text { Pertanian }\end{array}$ & PDB Total & \\
\hline 2003 & 3.079 .258 & 9.569 .242 & 66.088 .3 & 397.934 .3 & 1.94 \\
\hline 2004 & 3.293 .569 & 10.205 .592 & 66.502 .8 & 411.132 .1 & 2.00 \\
\hline 2005 & 3.348 .406 & 10.803 .423 & 231.613 .5 & 1.505 .216 .4 & 2.01 \\
\hline 2006 & 3.467 .458 & 11.343 .279 & 240.387 .3 & 1.577.171.3 & 2.00 \\
\hline 2007 & 3.643 .690 & 11.953 .885 & 248.222 .8 & 1.656 .825 .7 & 2.03 \\
\hline 2008 & 3.811 .540 & 12.619 .972 & 254.391 .3 & 1.749 .546 .9 & 2.07 \\
\hline 2009 & 4.243 .612 & 13.363 .620 & 262.402 .8 & 1.847.126.7 & 2.23 \\
\hline 2010 & 4.437 .448 & 14.275 .161 & 271.509 .3 & 1.964 .327 .3 & 2.33 \\
\hline 2011 & 4.691 .195 & 15.297 .770 & 284.620 .7 & 2.082 .315 .9 & 2.24 \\
\hline 2012 & 5.003 .834 & 16.274 .907 & 301.052 .2 & 2.247 .126 .8 & 2.29 \\
\hline 2013 & 5.259 .856 & 17.465 .253 & 329.021 .1 & 2.745 .342 .0 & 2.51 \\
\hline \multicolumn{5}{|c|}{ Jumlah rata - rata } & 2.11 \\
\hline
\end{tabular}

Dari hasil analisis LQ ( Location Quotion ) yang telah diteliti dan diperhitungkan, nilai LQ berdasarkan indikator pendapatan atas dasar harga konstan. Dari sektor pertanian sendiri merupakan komoditas basis dari tahun ke tahun dan rata - rata pertahunnya pun mencapai angka 2.11\% dan dari tahun 2003 sampai tahun 2013 dengan rincian hasil perhitungan ialah dari tahun 2003 sebesar 1.94\%, naik di tahun 20024sebesar 2.00\% ini bertanda sektor pertanian PDRB Provinsi Jambi terhadap sektor pertanian PDB Indonesia menempati sebagai komoditas yang basis yang mengalami lagi peningkatan secara terus menerus sejalan dengan waktu dari tahun 2005 naik lagi sebesar 2.01\% tahun 2006 mengalami sedikit penurunan sebesar 2.00\% tahun 2007 naik lagi menjadi 2.03\%, selanjutnya di tahun 2008 naik menjadi $2.07 \%$, di tahun 2009 sebesar 2.23\%, tahun 2008 sebesar $2.33 \%$, tahun 2010 turun menjadi 2.24\%, naik kembali di tahun 2012 sebesar 2.29\%, dan ditahun 2013 sebesar 2.51\%. uraian tersebut cukup untuk menyimpulkan bahwa pertanian menempati komoditas basis. Karena hasil nilai perhitungan LQ nya sampai atau lebih besar pada angka lebih dari satu. Bukan hanya nilai LQ pertahunnya saja menempati hasil LQ yang lebih dari satu, tetapi nilai rata ratanya juga menempati hasil LQ yang lebih dari satu yaitu sebesar $2.51 \%$. hal tersebut dapat disimpulkan bahwa sektor pertanian Provinsi Jambi merupakan salah satu sektor basis atau sektor unggulan di Provinsi Jambi. 


\section{Kesimpulan}

Dari uraian - uraian pada bab sebelumnya maka dapat disimpulkan sebagai berikut :

1. 2003 - 2013 kontribusi sektor pertanian menunjukan kontribusi yang cukup besar dengan rata - rata kontribusi pertahun menurut harga kontribusinya laju pertumbuhan PDRB sektor pertanian terhadap PDRB Provinsi Jambi adalah sebesar $5.16 \%$, dan dari hasil tersebut juga dapat dilihat bahwa sektor pertanian di Provinsi Jambi mengalami peningkatan dari tahun ke tahun sehingga merupakan sektor terpenting sebagai pendorong untuk pembangunan perekonomian Indonesia karena sektor pertanian inilah yang sebenernya menjadi penggerak utama dalam kegiatan pertumbuhan pembangunan daerah.

2. Berdasarkan Indikator pendapatan ( PDRB ) hasil LQ memperlihatkan bahwa komoditas pertanian di Provinsi Jambi selam tahun 2003 - 2013 PDRB atas harga konstan, sektor pertanian Provinsi Jambi terhadap sektor pertanian yang ditunjukan oleh nilai pertahunnya LQ > 1 dengan indikator pendapatan nasional merupakan sektor komoditas basis yang tertinggi pada tahun 2011 yaitu sebesar $2.11 \%$

\section{Saran}

Dari kesimpulan diatas maka ada beberapa saran yang dapat diberikan sehubungannya dengan perkembangan dan kontribusi sektor pertanian terhadap PDRB Provinsi Jambi.

1. Pemerintah hendaknya terus mengembangkan berbagai potensi yang ada di sektor pertanian melalui berbagai kebijakan agrobisnis dengan mendorong pembangunan sarana hasil pertanian, sehingga produk - produk yang dihasilkan oleh sektor pertanian sehingga mampu bersaing dengan Provinsi lain yang ada di Indonesia.

2. mengingat sektor pertanian di Provinsi Jambi merupakan sektor basis, dalam ran gka menjadikan sektor pertanian salah satu pertumbuhan ekonomi yang cukup tinggi maka perlu adanya perhatian dari pemerintah dalam pengelolaan sektor pertanian terutama perhatian kepada petani dan lahan yang ada, dengan cara memberikan bantuan alat operasional yang lebih modern untuk bertani sehingga produktifitas dan efektifitas petani dapat meningkat yang nantinya diikuti oleh peningkatan produksi pertanian di Provinsi Jambi, sehingga di masa depan sektor pertanian tetap menjadi sektor basis dan menjadi sektor pertanian sebagai leading sektor dalam pembangunan perekonomian di Provinsi Jambi 


\section{DAFTAR PUSTAKA}

2007 , Info Kuantitatif Jambi 42 Tahun Provinsi Jambi , Jambi

Bilas , Richrad A, 2008, Teori Ekonomi mikro, Rineke Cipta, Jakarta

Desmeliza , 2007 , Kontribusi Sektor Pertanian Terhadap PDRB Sektor Pertanian Provinsi Jambi, Skripsi ( tidak dipublikasikan )

Dilon , HS, 2007 , Kebijakan Pembangunan Pertanian di Indonesia, Sinar Grafika Jakarta

Djoyohadikusumo Soemitro, 2008 Ekonomi Pembangunan, PT Pembangunan, Jakarta.

Dumairy dan Nasir Bachtiar, 2008, Ekonomi Ketenagakerjaan, Andalas University Press, Padang.

Elfindri dan Nasir Bachtiar, 2008, Ekonomi Ketenagakerjaan, Andalas University Press Padang

Evawati , 2008, Kontribusi Sektor Pertanian Terhadap PDRB Provinsi Jambi, Skripsi ( Tidak dipublikasikan )

Lipsey, G, 2007 , Pengantar Ekonomi Terjemahan Erlangga, Penerbit PT. Erlangga Jakarta.

Mubyarto, 2007, Pengantar Ekonomi Pertanian, Edisi 6 , LP3ES, Jakarta

Pertadiredja , Ace, 2008, Ekonomika, UI Press, Jakarta

Singarimbun, Masri, 2008, Metode Penelitian Survei, LP3ES, Jakarta

Supranto , J , 2007, Statistik Deskriktif , LP FE - UI, Jakarta

Sukirno Sadono, 2008 , Pengantar Ekonomi Mikro, LP FE - UI , Jakarta 